\title{
Kardiovaszkuláris betegségek tegnap, ma és holnap?
}

\author{
Kékes Ede, Tóth Kálmán
}

PTE KK, I. sz. Belgyógyászati Klinika, Kardiológiai és Angiológiai Tanszék, Pécs

Levelezési cím:

Dr. Kékes Ede ny. egyetemi tanár, tudományos tanácsadó, e-mail: kekesede@gmail.com

„Engem a jövő érdekel, mert ott fogom eltölteni életem hátralévő részét”

Charles Franklin Kattering amerikai feltaláló

Az egyén egészségállapotát az egyes betegségekben a prevalencián túl leginkább a mortalitási adatok, az elvesztett életévek, valamint a születéskor és 60 éves korban várható élettartam jellemzik. 1950 óta világunkban az összes halálozás abszolút számban folyamatosan növekedett, azonban minden évben egyre nagyobb méretű csökkenés alakult ki az egyes korcsoportokban, kiemelten a 20-40 évesek között. Minden életcsoportban a kardiovaszkuláris betegségek a teljes halálozás domináló tényezői. Az elmúlt két évtized alatt a kardiovaszkuláris betegségek esetén a 100000 lakosra vonatkoztatott halálozás, valamint az elvesztett életévek - különösen reumás szívbetegség, stroke, iszkémiás szívbetegség, valamint cardiomyopathia terén - szignifikánsan csökkentek. A hazai mortalitási és vesztett életévekre vonatkozó adatok - bár folyamatosan javultak - nagymértékben rosszabbak a fejlett európai országok megfelelö jellemzőinél. A pozitív irányú világtrendek magyarázatát egyrészt az egészségügyi technológia jelentős fejlődése, a hatásos gyógyszerek alkalmazása, valamint - a világot folyamatosan sújtó gazdasági, környezeti és egyéb katasztrófák ellenére - az egészségügybe fektetett beruházások növekedése adja. Fontos tény, hogy a világban és hazánkban is végre magas szintű fejlesztési tervek készültek és készülnek. Erre utal a születéskor és 60 éves korban várható élettartam lassú, de folyamatos növekedése, amely remélhetően folytatódik a további években is.

Kulcsszavak: kardiovaszkuláris betegségek, halálozás, vesztett életévek, várható élettartam, epidemiológia

\section{Epidemiological Thoughts. Cardiovascular Diseases Yesterday, Today and Tomorrow?}

In addition to the prevalence of diseases, the individual's state of health is most often characterized by mortality data, lost years of life, and life expectancy at birth and at age 60 . Since 1950, the total number of deaths in our world has grown steadily, but every year there has been an ever-increasing decline in each age group, especially between 20 and 40 years. In all life groups, cardiovascular diseases are the dominant factors of total mortality. During the last two decades in case of cardiovascular diseases, the number of deaths and the loss of life years per 100,000 inhabitants especially rheumatic heart disease, stroke, ischemic heart disease and cardiomyopathy - have decreased significantly. Data on domestic mortality and lost years of life have improved steadily however, they were far worse than those in developed European countries. The positive trends in the world were driven by the significant development of health technology, the use of effective drugs and - despite the economic, environmental and other catastrophes - by the increase in investment in healthcare. It is an important fact that high-level development plans have been and are being prepared in the world and in Hungary as well. This is evidenced by the slow but steady increase in life expectancy at birth and at the age of 60 , which will hopefully continue in the next years.

Keywords: cardiovascular diseases, mortality, years of life lost, life expectancy, epidemiology 
Az 1993-as évben egy igen jelentős lépés volt a Világbank Egészség-Fejlesztési Riportja, amelyben egy bizottság felülvizsgálta az egészségügybe történő befektetések irányait és új kereteket hozott létre annak érdekében, hogy a világ különböző régióiban az addigi igen kedvezőtlen egészségállapot megváltozzon és az egészségállapotot legjobban sújtó betegségek terén drámai javulás következzen be 2035-re (1). A mostani nemzedékünkre jellemző, hogy van elegendő pénzügyi és egyre magasabb szintű technológiai ismeret és kapacitás, s így jelentős mértékben csökkenhetnek a fertőző betegségek, valamint a gyermek és anyai halálozás aránya a világ minden táján. Érvényes ez a kardiovaszkuláris és más krónikus betegségek vonatkozásában is. A Lancetben 2013-ban megjelent eszmefuttatás (2) szerint megindult egy kedvező halálozási tendencia, a "Grand Convergence” és ez a kedvezőbb „Egészséghelyzet" valóban elérhető lesz a mi, vagy méginkább gyerekeink életében. Ehhez füződik szorosan, hogy 2011-ben a nem fertőző betegségekről (kardiovaszkuláris betegségek, stroke, diabétesz, daganatos betegségek, krónikus légzőszervi betegségek) szóló ENSZ értekezleten egyhangú állásfoglalás született, amely szerint az összes nemzet számára kulcsfontosságú célkitǔzés, hogy ezen betegségekben a korai halálozást 25\%-kal csökkentsék 2025-re (3). Kiemelten a kardiovaszkuláris (CV) betegségeket hangsúlyozták, innen a program elnevezése „Heart of 25 by 25” (4). Ennek érdekében a tervben 4 kiemelt célkitűzés szerepel: - a kor, nem, nemzetspecifikus dohányzásprevalencia $30 \%$-os csökkentése,

- a >140 Hgmm szisztolés vérnyomásúak 25\%-os csökkentése,

- a 2-es típusú diabétesz növekedésének megállítása,

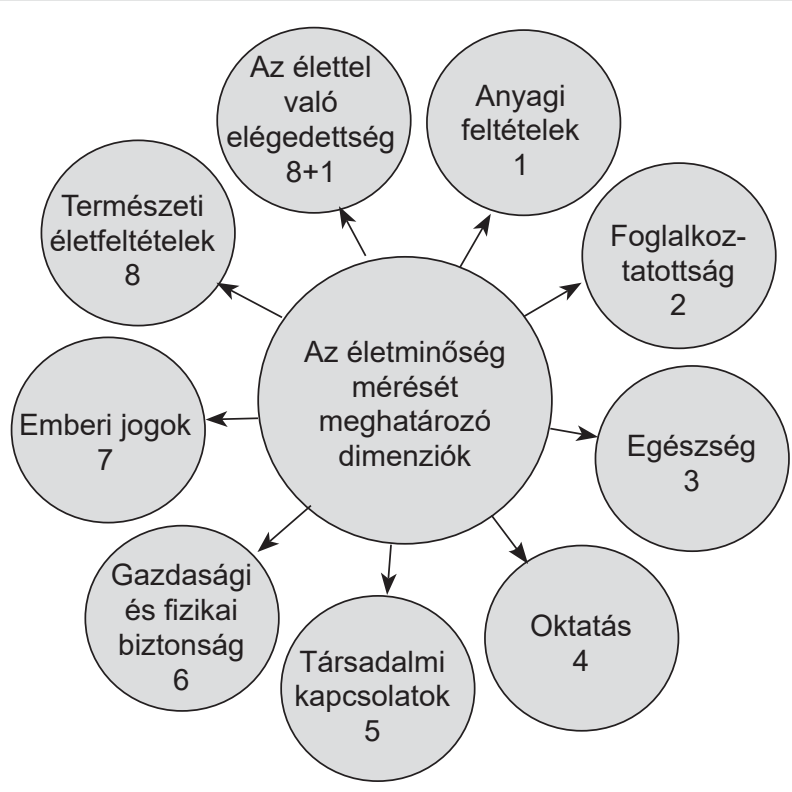

1. ÁBRA. Az életminőség mérésére kialakított dimenziók
- az elhízás folyamatos növekedési trendjének megállítása.

Az egészségállapot meghatározása nem egyszerü feladat, mert sok összetevőből áll. 2013-ban az Eurostat létrehozott a jövedelemmel és az életfeltételekkel foglalkozó részlegen belül (EU-SILC - EU Statistics on Income and Living Conditions) egy ad hoc modult a „szubjektív jólét" meghatározására (5). Ennek a feladata az volt, hogy az életminőség rendelkezésre álló objektív (statisztikákkal alátámasztott) dimenzióit kiegészítse úgynevezett mikroadatokkal, azaz az embereknek az életminőségről alkotott észleléseivel (1. ábra).

$A z$ 1. ábra világosan mutatja, hogy a „globális egészség állapot"-ot, mint életminőséget számos tényező befolyásolja, és ennek csak egyik dimenziója a valódi értelemben vett egészség, amelyet még számos tényező befolyásol az ismert betegségeken kívül (6).

A legfontosabb jellemzők, amelyek a CV betegségekben jelzik az egyén egészségállapotát:

- mortalitási adatok,

- betegségprevalencia,

- várható élettartam születéskor és 60 éves korban,

- elvesztett életévek (YLL).

Vizsgáljuk meg az egyes tényezőkre jellemző adatokat az elmúlt évtizedektől a mai időszakig.

\section{Mortalitási adatok}

Az összes regisztrált mortalitás tekintetében kétfajta változás figyelhető meg az 1950 és 2017 közötti időszakban: a teljes világhalálozás 1950-ben az összlakosság 18,7\%-a (18,4-19 Cl) volt, amely 58,8\%-kal $(58,2-59,3 \mathrm{Cl})$ emelkedett 2017-ig, ekkor férfiaknál abszolút számban 30387000 fö, nőknél 28558000 fő volt (7). Abszolút számokban ez nem is annyira rossz tendencia, mert közben a Földünk lakossága 2,57 milliárdról 7,64 millárdra növekedett és ez viszont 297\% emelkedés (7).

Ha megvizsgáljuk, hogy az egyes években az életévcsoportokra bontott - mindkét nemre vonatkozó logaritmikus skálájú - 100000 lakosra vonatkozó halálozási ráta hogyan változik, akkor azt találjuk, hogy 1950-től minden évben nagyobb méretü csökkenés alakul ki az egyes korcsoportokban. Ugyanakkor ez a csökkenés folyamatosan lassul és elenyészik az életkor előrehaladásával. A legnagyobb méretű változás (csökkenés) a 20-40 év között jött létre. Ez azt jelenti, hogy ezekben a korcsoportokban egyre jobban sikerült a betegségeket befolyásolni a jelzett időszakban. A 20-40 év közötti jellemző változásokat mutatjuk be a 2 . ábrán.

$\mathrm{Az}$ adatokat elemezve világos, hogy a korszerü diagnosztikai módszerek, a szürések terjedése miatt az abszolút szám nő (a betegségek prevalenciája is emelkedik), ugyanakkor a már kialakult betegségek befolyásolása javult, legnagyobb mértékben a 20-40 év közötti korosztályban. 


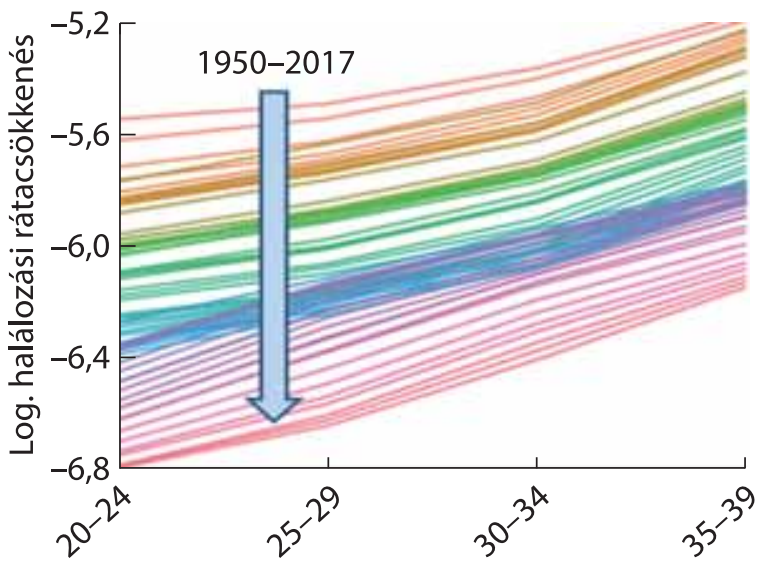

2. ÁBRA. A logaritmikus halálozási ráta csökkenése 20-40 év között 1950-től 2017-ig. GBD-2017 adatai alapján (7)

Amennyiben az 1990 és 2016 közötti regisztrált halálozási arányokat a betegségcsoportok közötti megoszlásban nézzük, akkor látjuk, hogy minden korcsoportban 2016-ra szignifikáns növekedés $(p<0,01)$ alakult ki. A növekedés különösen kiemelkedő volt 50-80 év között. Amennyiben a mortalitás okait vizsgáljuk betegségcsoportok alapján, látszik, hogy minden életkori csoportban domináló tényező a CV betegségek, és a két időpont között ebben is szignifikáns növekedés $(p<0,001)$ figyelhető meg (8) (3. ábra). A növekedés magyarázata, hogy egyre több beteget észlelt az egészségügyi ellátórendszer a

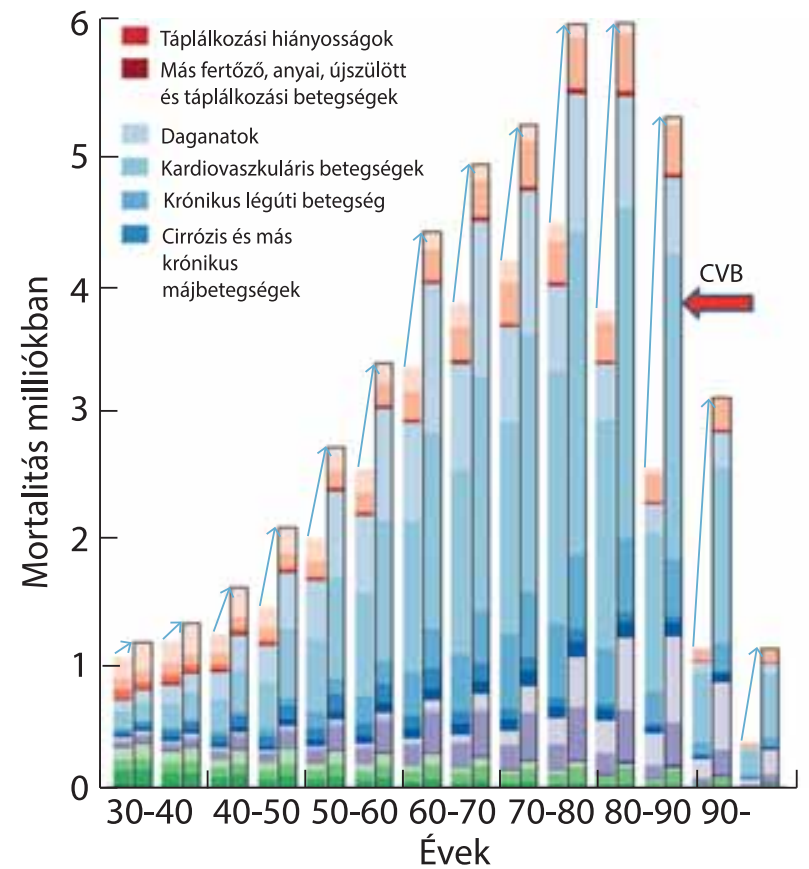

3. ÁBRA. A különböző halálokok okozta mortalitás milliókban 1990-2016 között, korcsoportos bontásban. GBD 2016 adatai alapján (8) (A nyilak az 1990 és 2016 közötti változást jelölik) szürések növekedése és a diagnosztikus módszerek fejlődése miatt.

Amennyiben helyes az az állítás, hogy az utóbbi évtizedben jelentős erőfeszitéseket tettünk a CV betegségek megelőzése és kezelése terén, akkor ennek a statisztikai adatokban is tükröződnie kell. 2006-tól már részletesebb feldolgozásokat végeztek, ezért megvizsgáltuk, hogy egy évtized alatt hogyan változott az egyes CV betegségekben a mortalitás. Ezt legjobban a GBD2016 elemzés (8) mutatta, amely arra utalt, hogy egy évtized alatt a kor korrigált, a 100000 lakosra vonatkozó CV mortalitás 14\%-kal csökkent. A legnagyobb méretü csökkenés a reumás szívbetegségek és a stroke esetében alakult ki (26,9-21\%), de jelentős a csökkenés iszkémiás szívbetegségben, cardiomyopathiában és aorta aneurizma terén is (10\% körüli) $(1$. táblázat).

A betegségek elleni küzdelem sikerének másik mutatója a 100000 lakosra vonatkozó elvesztett életévek (Years Lost Life) mérése. A várakozásnak megfelelően ebben a vonatkozásban még nagyobb méretü kedvező változás jött létre csaknem hasonló megoszlásban, mint a mortalitás esetében (2. táblázat).

Vizsgáljuk meg a kérdést a magyarországi NEFI-adatok alapján is (9). A hazai összes halálozás tekintetében szignifikánsan csökkenő tendencia figyelhető meg 2005 és 2013 között. Ennek ellenére 2013-ban a magyar halálozási arány férfiaknál 173\%-kal, nőknél 158\%-kal volt magasabb, mint az EU15 országokban. 2015-ben nőknél a CV halálozás az összes halálozás 54,6\%-a, férfiaknál 44\%-a volt. Amennyiben a CV halálozást részletesen elemezzük (10), akkor érdekes megfigyeléseket tehetünk: férfiaknál szignifikáns csökkenés történt a regisztrált összes mortalitásban, nőknél értékelhető változás nem történt (3. táblázat).

A további bontásnál csak a miokardiális infarktus (AMI), az iszkémiás szívbetegség (ISZB) és az agyi esemé-

1. TÁBLÁZAT. A CV betegségek okozta mortalitás/100 000 lakos. Százalékos változás 2006-2016 között. Világadatok GBD 2016 adatai alapján (8)

\begin{tabular}{|l|l|c|}
\hline Betegség neve & $\begin{array}{l}\text { 2016 kor korri- } \\
\text { gált mortalitás/ } \\
100000 \text { (átl. Cl) }\end{array}$ & $\begin{array}{l}\text { Változás \% } \\
\text { 2006-2016 } \\
\text { között }\end{array}$ \\
\hline $\begin{array}{l}\text { Kardiovaszkuláris } \\
\text { betegség }\end{array}$ & $277,9(272,1-284,6)$ & $-14,5$ \\
\hline Reumás szívbetegség & $4,7(4,5-4,9)$ & $-26,9$ \\
\hline Iszkémiás szívbetegség & $149,7(145,8-154,7)$ & $-11,6$ \\
\hline Agyi vaszkuláris betegség & $86,5(83,3-89,9)$ & $-21,0$ \\
\hline Hipertóniás szívbetegség & $14,3(11-15,7)$ & $-4,4$ \\
\hline Cardiomyopathia & $5,2(4,3-5,7)$ & $-13,0$ \\
\hline Pitvarfibrilláció & $4(3,2-5)$ & $-1,1$ \\
\hline Aorta aneurizma & $2,6(2,6-2,7)$ & $-10,1$ \\
\hline PAD & $1(0,8-1,5)$ & $-2,6$ \\
\hline Egyéb & $8,4(7,8-9,9)$ & $-9,8$
\end{tabular}


2. TÁBLÁZAT. A kor korrigált elvesztett életévek/100 000 lakos. Százalékos változás 2006-2016 között. Világadatok GBD 2016 adatai alapján (8). YLL=Years Lost Life

\begin{tabular}{|l|l|l|}
\hline Betegség neve & $\begin{array}{l}\text { 2016 kor korri- } \\
\text { gált Y LL/100 000 } \\
\text { (átl. CI) }\end{array}$ & $\begin{array}{l}\text { Változás \% } \\
2006-2016 \\
\text { között }\end{array}$ \\
\hline $\begin{array}{l}\text { Kardiovaszkuláris } \\
\text { betegség }\end{array}$ & $\begin{array}{l}4683,9 \\
(4580,4-4794,3)\end{array}$ & $-15,7$ \\
\hline $\begin{array}{l}\text { Reumás szívbetegség } \\
116,5(111,1-122,7)\end{array}$ & $-30,1$ \\
\hline Iszkémiás szívbetegség & $2461,1(2398-2530)$ & $-12,3$ \\
\hline Agyi vaszkuláris betegség & 1496,8 & $-21,5$ \\
\hline Hipertóniás szívbetegség & $(1451,8-1542,8)$ & \\
\hline Cardiomyopathia & $221,7(178,6-241,8)$ & $-7,2$ \\
\hline Pitvarfibrilláció & $114,7(99,2-126,6)$ & 16,5 \\
\hline Aorta aneurizma & $17,3(13,9-19)$ & $-18,1$ \\
\hline PAD & $42,6(41,4-43,9)$ & $-10,9$ \\
\hline Endocarditis & $11,2(8,5-15,9)$ & $-4,2$ \\
\hline Egyéb & $33(29,2-39,1)$ & $-1,3$ \\
\hline & $149,1-182,7$ & $-11,2$ \\
\hline
\end{tabular}

3. TÁBLÁZAT. Az összes halálozás Magyarországon férfiaknál és nőknél. (Saját összeállítás a KSH adatok alapján) (9)

\begin{tabular}{|c|c|c|}
\hline Évek & Férfi & Nő \\
\hline 1990 & Összes halál férfi & Összes halál nö \\
\hline 2000 & 76936 & 68724 \\
\hline 2005 & 70475 & 65126 \\
\hline 2010 & 69795 & 65951 \\
\hline 2015 & 65137 & 65319 \\
\hline 2017 & 63545 & 68152 \\
\hline
\end{tabular}

nyek okozta (CVB) halálozási adatokat találtuk. Ezeket a 4. táblázaton és a 4. ábrán mutatjuk be.

A bemutatott adatok szerint az AMI- és a stroke-halálozásban 1990-től egyenletes, szignifikáns csökkenési tendencia érvényesült. ISZB esetén 2000-2005 között ugrásszerü emelkedés alakult ki, amely azóta is tart. Ezen időszaktól nőknél diszkrét növekedés, míg férfiaknál „stagnálás” figyelhető meg.

Összehasonlítást végeztünk az Európai Közösség (EU 15) adatai és a magyar adatok között. A 100000 lakos- ra vonatkoztatott kor korrigált összes mortalitás tekintetében a magyar női populáció az EU 15 férfi halálozás szintjén van, a férfiak kirívóan nagyobb halálozási arányokat mutatnak az európai átlagnál. Mind az összeurópai, mind a magyar halálozás egyenletesen csökkent 2005 és 2015 között $(11,12)$ (5. ábra).

Magyarországon a 100000 lakosra számított elvesztett egészséges életévek (YLL) terén - az Európai Közösség országainak átlagához hasonlóan - erősen szignifikáns ( $p<0,001)$ csökkenési trend jött létre 1990 és 2015 között (9). Hasonló csökkenés figyelhető meg Szlovákiában, Csehországban és Lengyelországban is, azonban minden mért időpontban a legnagyobb érték hazánk esetében volt. Ugyanakkor a gazdaságilag fejlettebb nyugat-európai országokhoz képest jelentősen elmaradtunk, ha a 2013-2014. évi adatokat hasonlítjuk össze (13). Az 5. táblázat jelzi, hogy milyen különbségek vannak az egyes európai országok között az YLL tekintetében is.

Az elmúlt 20-30 év alatt kialakult trendek alapján az alábbi következtéseket vonhatjuk le:

- A keringési rendszer betegségei voltak felelősek az elvesztett egészséges életévek egyötödéért, és mindkét nem esetében ezek a legfőbb egészségveszteséget okozó tényezők. Ezek több mint feléért az iszkémiás szívbetegség felelt, egynegyedéért pedig az agyi érbetegségek. Ezen két kiemelt betegség okozta veszteség 1990 óta fokozatosan csökken, régiók, illetve országok szerint különböző mértékben.

- A CV betegségek kialakulásában szerepet játszó tényezők, mint a hipertónia, helytelen táplálkozás, fizikai inaktivitás okozta elhízás (világ endémia), hyperlipidaemia, diabetes mellitus, dohányzás jól ismertek (14-19), azonban az ismertség azt is jelenti, hogy folyamatosan egyre növekvő mértékben van lehetőség beavatkozásra, az egészségi állapot javítására $(2,3)$.

- A hazai CV mortalitás is egyértelmü csökkenést mutatott az elmúlt két évtizedben és ez érvényes az elvesztett életévekre is. A részletes bontásnál az a tény, hogy az AMI és a stroke-mortalitás szignifikánsan csökkent, ugyanakkor az iszkémiás szívbetegségnél növekedés, illetve stagnálás alakult ki 2005 óta, azzal magyarázható, hogy egyre jobb itthon is a betegsé-

4. TÁBLÁZAT. A miokardiális infarktus (AMI), az iszkémiás szívbetegség (ISZB) és a stroke (CVB) okozta regisztrált halálozás 1990-2017 között

\begin{tabular}{|l|c|c|c|c|c|c|}
\hline & AMI férfi & AMI nö & ISZB férfi & ISZB nö & CVB férfi & CVB nő \\
\hline 1990 & 8540 & 5912 & 6776 & 6963 & 9556 & 11662 \\
\hline 2000 & 6530 & 4782 & 8123 & 10361 & 8559 & 10380 \\
\hline 2005 & 5865 & 4352 & 11664 & 14682 & 6837 & 8720 \\
\hline 2010 & 4013 & 3223 & 11210 & 15229 & 5804 & 7918 \\
\hline 2015 & 3359 & 2669 & 11249 & 15738 & 5448 & 7052 \\
\hline 2017 & 3250 & 2508 & 11591 & 15306 & 4960 & 6424 \\
\hline trend $p$ & $<0,001$ & $<0,001$ & & & $<0,001$ & $<0,001$ \\
\hline
\end{tabular}




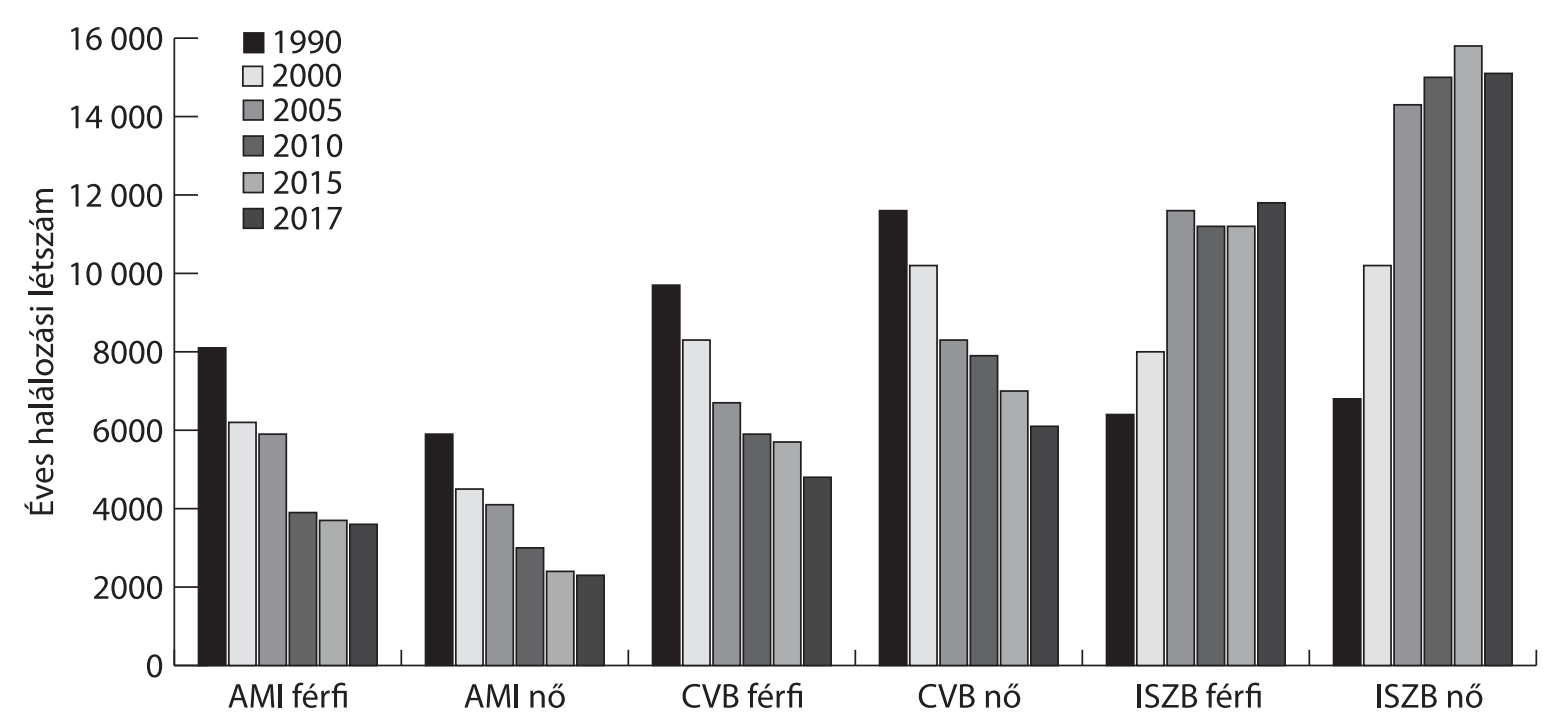

4. ÁBRA. A hazai éves halálozási szám 1990-2017 között AMI, ISZB és stroke esetében nemek szerinti bontásban. Saját feldolgozás KSH-adatok alapján (10)

gek szürése, a diagnosztika, és így lényegesen több beteg kerül felismerésre. Másrészt az AMI és stroke szignifikáns csökkenése feltehetően jelzi az alap rizikótényezők befolyásolásának, valamint a betegségek gyógyszeres, intervenciós kezelésének nagyobb méretü fejlődését, sikerét. Ugyanakkor az is világos, hogy a hazai CV mortalitási és YLL-adatok még mindig igen nagymértékben rosszabbak, mint az európai átlagok és messze rosszabbak, mint a fejlett európai országok (EU15) megfelelő jellemzői.

A CV betegségek kialakulását, kezelését, valamint a morbiditási és mortalitási arányok csökkentését számos nem befolyásolható és befolyásolható tényező szabályozza, amelyek kihatással vannak a CV fö kockázati faktorokra is. A legfontosabb kockázati tényezők, a klasszikus rizikófaktorok és a CV-betegségek, illetve azok komplikációi közötti összefüggést a 6 . ábrán mutatjuk be.

5. TÁBLÁZAT. A 100000 lakosra vonatkoztatott kor korrigált egészséges életvesztés (YLL) Európa különböző országaiban (13)

\begin{tabular}{|l|r|r|r|r|r|}
\hline Ország & $\begin{array}{c}\text { Idö- } \\
\text { pont }\end{array}$ & $\begin{array}{c}\text { Össz. } \\
\text { halál }\end{array}$ & CVB & IHD & $\begin{array}{c}\text { St } \\
\text { roke }\end{array}$ \\
\hline Oroszország & 2013 & 19040 & 5297 & 2613 & 963 \\
\hline Litvánia & 2014 & 12557 & 3094 & 1679 & 479 \\
\hline Bulgária & 2014 & 9359 & 3662 & 911 & 698 \\
\hline Magyarország & 2014 & 8130 & 2259 & 1134 & 379 \\
\hline Csehország & 2014 & 6491 & 1321 & 683 & 183 \\
\hline Németország & 2014 & 4553 & 872 & 407 & 104 \\
\hline Franciaország & 2014 & 4765 & 538 & 205 & 94 \\
\hline Ausztria & 2014 & 4196 & 678 & 375 & 93 \\
\hline Hollandia & 2014 & 3477 & 650 & 203 & 94 \\
\hline Svédország & 2014 & 3403 & 582 & 280 & 89 \\
\hline
\end{tabular}

Fentiek függvényében vizsgáljuk meg, milyen okokkal magyarázhatók ezen pozitív változások, világtrendek a halálozás, illetve az elvesztett életévek tekintetében. - A technológiai fejlődés jelentősége. Ide az új eszközöket, eljárásokat és az egyre hatásosabb gyógyszereket egyaránt besorolhatjuk. A fejlődés ezen a téren különösen az AMl és a stroke vonatkozásában (koronária-intervenciók, trombolízis, angiográfiás eszközök és módszerek fejlődése stb.) érvényesült, de a magas vérnyomás és a hyperlipidaemia befolyásolása terén is jelentős elörelépések történtek (RAAS-gátlók széleskörủ alkalmazása, statinok kiterjedt használata stb.). - Világbanki adatok alapján (nemzeti egy före eső jövedelmi elemzések szerint) a szegény jövedelmű populáció aránya 1990-2011 között 57,8\%-ról 36,3\%-ra csökkent, míg a szegény-közepes jövedelműek aránya 12,7\%-ról 35,7\%-ra emelkedett annak ellenére, hogy a világban folyamatosan gazdasági és politikai katasztrófák érvényesülnek (21).

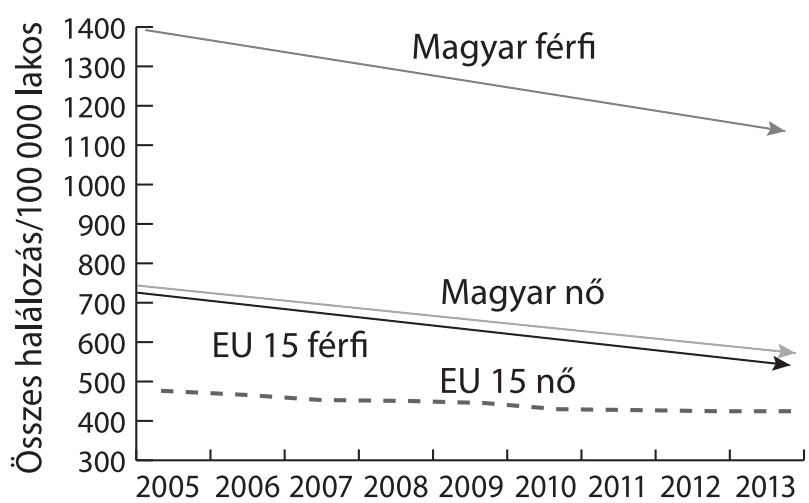

5. ÁBRA. A 100000 lakosra vonatkoztatott összes halálozás. Az EU 15 országok átlaga és a magyar halálozás összehasonlítása nemek szerinti bontásban (12) 


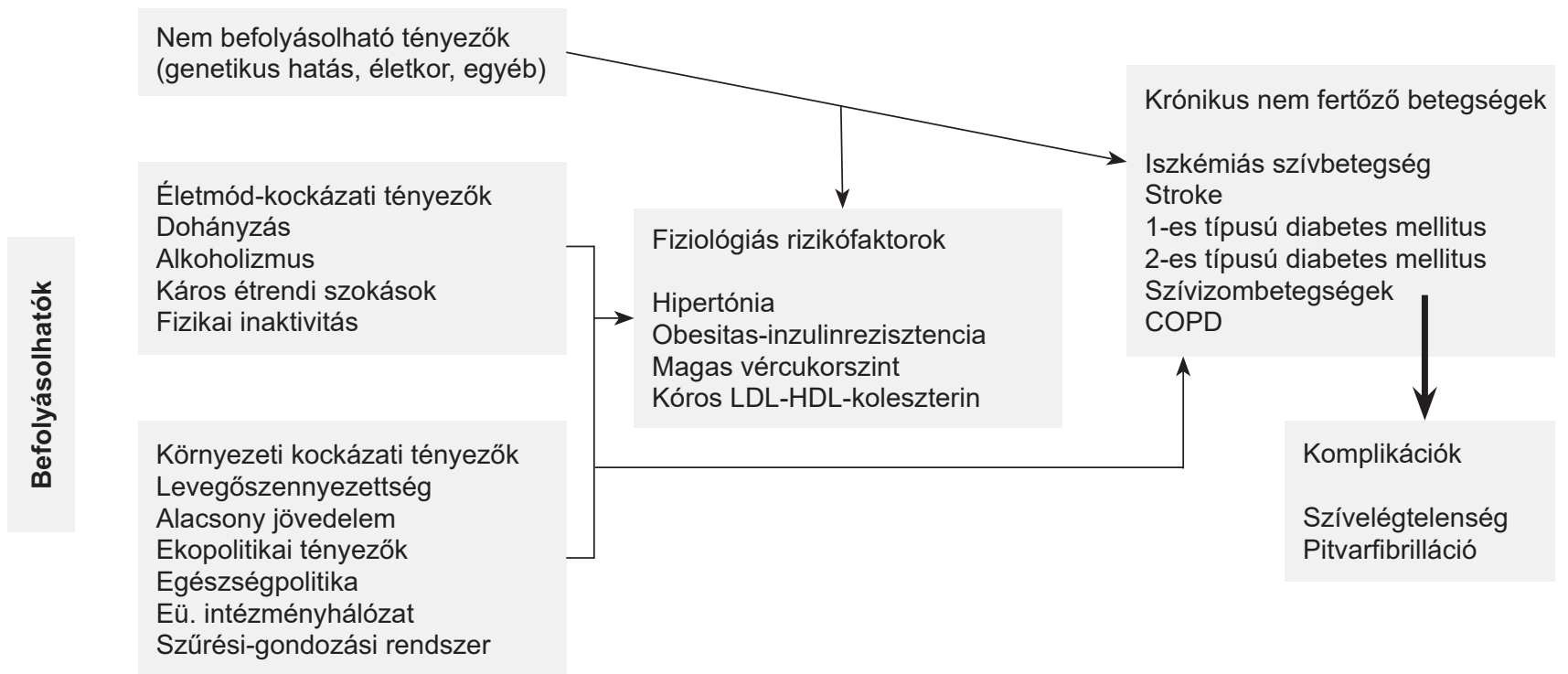

6. ÁBRA. A kockázati tényezők, a fiziológiás rizikófaktorok és a CV betegségek kapcsolatrendszere

- Elörelépések történtek a CV betegségek primer és szekunder prevenciója területén, valamint a lakossági együttműködésre alapozott prevencióban diabetes mellitusban (2). Ehhez tartozik, hogy kialakulóban van egy olyan szemlélet, amely a megelőzést, gyógyítást és a rehabilitációt egységnek és egyidejünek tekinti. Ez az EGÉSZSÉG-et a központba helyező szemlélet egyúttal szükségessé teszi a gyógyító-megelőző, a szociális, a foglalkoztatási és az oktatási rendszerek szoros együttmüködését, illetve a gazdasági és társadalmi feltételek biztosítását $(22,23)$.

- Az egész világra kiterjedő mozgalmak, programok, amelyek befolyásolhatják az emberek hozzáállását vagy ismeretét adott kockázati tényezőkről, betegségekről. Ide sorolhatjuk az IMF által indított World Diabetes Day 2018-2019 mozgalmat (24), vagy az ISH által indított May Measurement Month 2019-2018 (MMM) programot (25), amelyek révén bővítették a lakosság ismeretét ezen betegségekről, és a világ számos helyén vérnyomás- és vércukormérések történtek, ott is, ahol eddig ez a kérdés fel sem merült (26, 27). A „Stop Só” európai program (28) ugyancsak jelentős előrelépést eredményezett a CV-prevencióban (pékárukban a sótartalom csökkentése) (28). Ezen a téren Magyarországon kiemelkedőnek tartható a „Magyarország Átfogó Egészségvédelmi Szűrőprogramja (MÁESZ) 2010-2017” program (29), vagy az „Éljen 140/90 alatt" mozgalom (30), de igen sikeresek és hasznosak például az Egy Csepp Figyelem Alapítvány országos rendezvényei is a cukorbetegség korai felismerése terén.

- Számottevő eredményeket értünk el olyan klasszikus kockázati tényezők visszaszorításában, mint a dohányzás, fizikai inaktivitás, bár még mindig - különösen hazánkban - nem elegendő mértékben (31).
- Az egészségügyi struktúrák újraszervezésének folyamata megindult a gazdaságilag fejletlen országokban, másrészt a fejlett országokban is jelentős növekedés jött létre. Egyúttal az egészségellátó „team”-ek szorosabb kapcsolatot alakítottak ki a betegekkel, nagyobb lett az orvos-beteg-együttműködés. Ehhez az is hozzájárult, hogy a technikai fejlődés révén a betegek egészségtudata emelkedett, és aktivitásuk növekedett saját betegségük kezelésében, gondozásában $(2,31,32,33)$. A telemedicina óriási fejlődést indított ezen a téren (okos eszközök, telefonok, webfelületek stb. használata) (34).

\section{Mi várható és miért a ko̊vetkező 20 évben?}

Az eddigi kedvező világtendenciák arra is utalnak, hogy jelentős nemzetközi, nemzeti és magán invesztálások történtek az egészségügyben, amelyek az innovációs törekvéseket is segítették a technológia, informatika, telemedicina területén $(35,36,37)$.

A további előrelépés első lépcsőjét az jelentette, hogy az ENSZ („The Heart of 25 by 25” (4), a WHO (38) és a Világbank (21), valamint az egyes országok egészségügyét irányító szervezetek, apparátusok konkrét, előremutató terveket készítettek a CV betegséget előidéző kockázati tényezők visszaszorítása érdekében (39). A „Global Health 2035” világelemzés világosan összefoglalja a jövő lehetőségeit (2). 2018-ban hazánkban is elkészült egy előremutató terv a CV betegségek megelőzésének kérdésében (40). A WHO akcióterve (38) szerint a „4 fő közellenség” (szív-ér rendszeri betegségek, diabetes mellitus, COPD, daganatok), azaz a legfőbb nem fertőző betegségek okozta halálozást 25\%-kal kell csökkenteni 2025-re. A 6 fö rizikófak- 
6. TÁBLÁZAT. A születéskor és 60 éves korban várható élettartam a világban és néhány általunk kiemelt országban

\begin{tabular}{|l|c|c|c|c|}
\hline & \multicolumn{2}{|c|}{$\begin{array}{c}\text { Várható } \\
\text { élettartam } \\
\text { születés kor (év) }\end{array}$} & \multicolumn{2}{c|}{$\begin{array}{c}\text { Várható élet- } \\
\text { tartam 60 éves } \\
\text { korban (év) }\end{array}$} \\
\hline & Férfi & Nö & Férfi & Nö \\
\hline Világ & 70,48 & 75,59 & 19,39 & 22,60 \\
\hline Kanada & 79,86 & 83,99 & 23,50 & 26,42 \\
\hline Finnország & 78,55 & 84,28 & 22,10 & 27,84 \\
\hline Franciaország & 79,82 & 85,74 & 23,38 & 27,84 \\
\hline Németország & 79,56 & 83,99 & 23,50 & 26,47 \\
\hline Csehország & 76,31 & 81,96 & 19,95 & 24,06 \\
\hline Magyarország & 73,19 & 80,20 & 18,13 & 23,02 \\
\hline
\end{tabular}

tor (dohányzás, alkoholfogyasztás, sóbevitel, elhízás, emelkedett vérnyomás és vércukorszint) megfelelő kontrolljával sikeresen lehetne csökkenteni a CV-halálozást is. Ezen célkitűzések hazai megvalósítása csak a már említett egészség-szemléletváltással, a prevenciós feladatok újraszervezésével oldható meg (22, 23, 31). A tervek, feladatok részleteinek bemutatása nem jelen közleményünk célja.

A jelenleg kialakuló tendenciák feltehetően a továbbiakban is érvényesülni fognak, sőt a szakértők szerint még növekedni tudnak. Miben foglalhatók össze ezen tevékenységek (2)?

- A folyamatosan növekvő invesztálás az egészségügyi szektorokba világszerte tovább fogja emelni az egészségügyben használatos technológia és infrastruktúra megindult és rohamos fejlődését.

- Az egyes országokban érvényesülő egészségügyi beruházások és hibás prevenciós rendszerek korrigálása megállíthatatlan, mert az egyénekben folyamatosan növekszik a „saját egészség fontosságának felismerése" és ez sikeres társadalmi kezdeményezésekhez vezet.

- A gazdasági növekedés a világ számos régiójában és országában elősegíti a fenti folyamatokat (41).

A krónikus nem fertőző betegségeket, illetve ezen belül a CV-betegségekben bekövetkező kedvező változásokat legjobban a születéskor, illetve a 60 éves korban várható élettartammal lehet lemérni. Zárógondolatként ezen indikátorokban végbemenő folyamatokat szeretnénk bemutatni a világban, ezen belül Európában és hazánkban, illetve a velünk szomszédos országokban. 2004 és 2015 között az Európai Közösség 18 országában a születéskor várható élettartam fokozatosan emelkedett mindkét nemben, nőknél minden évben nagyobb a várható élettartam $(18,42)$. A magyarországi adatoknál (HUN) látjuk, hogy a magyar nők és férfiak szignifikánsan alacsonyabb életévet mutatnak a megfelelő EU átlagnál (7. ábra).

A GBD 2017. évi adatai alapján (7) készített összeállításunkban (6. táblázat) világosan látszik, hogy milyen különbség van a világ- átlag és az egyes országok kö-

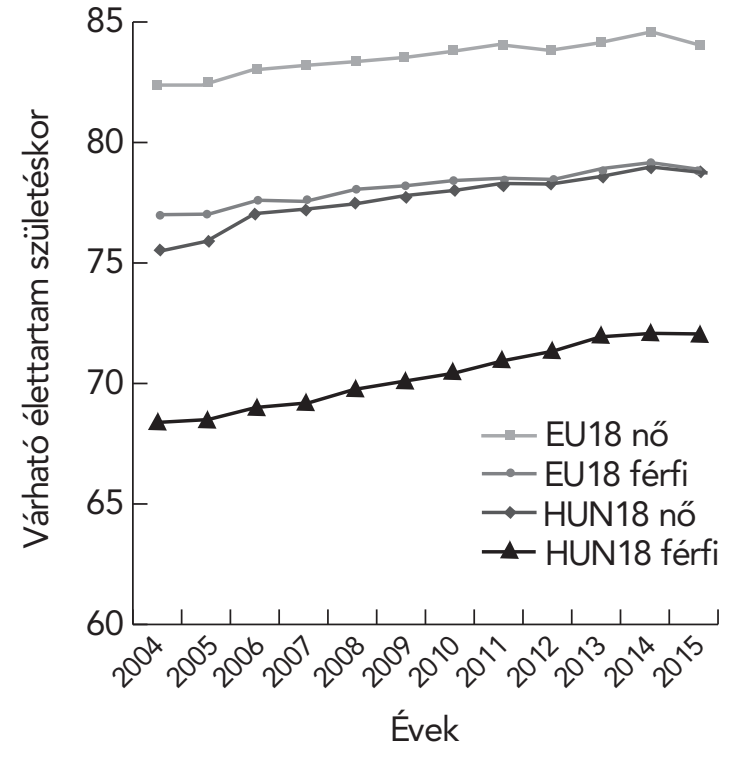

7. ÁBRA. Születéskor várható élettartam években. EurópaMagyarország. Eurostat 2004-2015 adatai alapján (42)

zött. Sajnos a magyar adatok - bár jobbak a világátlagnál - a fejlett országokhoz képest jelentősen elmaradó mutatókat jeleznek. Az általánosan növekvő tendencia azonban ad biztatást a jövő nemzedékének is.

\section{Irodalom}

1. World Bank. 1993. World Development Report 1993: Investing in Health. New York: Oxford University Press. (C) World Bank. https:// openknowledge.worldbank.org/handle/10986/5976 License: CC BY 3.0 IGO.

2. Dean T Jamison*, Lawrence H Summers*, George Alleyne. et al. Global health 2035: a world converging within a generation. Lancet 2013; 382: 1898-955. http://dx.doi.org/10.1016/S01406736(13)62105-4

3. Kékes E, Szegedi J, Kiss I. A korai kardiovaszkuláris mortalitás csökkentésének ENSZ terve 2025-ig, és a program sikerének becslése. LAM 2017; 27(8-9): 330-8.

4. Sacco RL, Roth GA, Reddy KS, et al. The Heart of 25 by 25 : Achieving the Goal of Reducing Global and Regional Premature Deaths from Cardiovascular Diseases and Stroke. A Modeling Study from the American Heart Association and World Heart Federation, Circulation 2016; 133: e674-e690. https://doi.org/10.1161/ CIR.0000000000000395

5. Eurostat: Quality of life - facts and views, 2015 edition. Europeaan Union: Luxemburg Publication Office of the European Union; pp. 1-264.

6. Rekettye G, Kékes E. Az életminőség összehasonlító elemzése az európai országokban. Hypertonia és Nephrologia 2016; 20(4): 167-70.

7. GBD 2017 Mortality Collaborators. Global, regional, and national age-sex-specific mortality and life expectancy, 1950-2017: a systematic analysis for the Global Burden of Disease Study 2017. Lancet 2018; 392: 1684-735. www.thelancet.com/pdfs/journals/lancet/ PIIS0140-6736(18)31891-9.pdf

8. GBD 2016 Causes of Death Collaborators*Global, regional and national age-sex specific mortality for 264 causes of death, 19802016: a systematic analysis for the Global Burden of Disease Study 2016. Lancet 2017; 390: 1151-210 /doi.org/10.1016/S0140- 
6736(17)32152-9

9. Nemzeti Egészségfejlesztési Intézet (nefi) 2017. Egészségjelentés 2016 http://www.egeszseg.hu/szakmai_oldalak/assets/intezetunkrol/egeszsegjelentes-2016_uj.pdf

10. KSH Tájékoztatási adatbázis 2018. 1.5. Halálozások a gyakoribb halálokok szerint (1990-). http://www.ksh.hu/docs/hun/xstadat/xstadat_eves/i_wnh001.html

11. European WHO Mortality Database 2015. http://apps.who.int/ healthinfo/ statistics/mortality/whodpms/-indicator-database-mortality-indicators-by-67-causes-of-death,-age-and-sex-hfa-mdb.

12. WHO European Health for All Database (HFA-DB) http://www. euro.who.int/en/data-and-evidence/databases/european-health-forall-family-of-databases-hfa-db

13. Wilkins E, Wilson L, Wickramasinghe K, et al. European Cardiovascular Disease Statistics 2017. European Heart Network, Brussels www.ehnheart.org

14. Rahimi K, Emdin CA, MacMahon S. The Epidemiology of Blood Pressure and Its Worldwide Management. Circ Res 2015; 116: 925 36. doi: 10.1161/CIRCRESAHA. 116.304723

15. Townsend N, Nichols M, Scarborough P, and Rayner M. Cardiovascular disease in Europe - epidemiological update 2015. European Heart Journal 2015; 36, 2696-705. doi:10.1093/eurheartj/ehv428 16. Shaw JE, Sicree RA, Zimmet PZ. Global estimates of the prevalence of diabetes for 2010 and 2030. Diabetes Research and Clinical Practice 2010; 87: 4-14. doi.org/10.1016/j.diabres.2009.10.007 17. Ngu M, Fleming $T$, Robinson $M$, et al. Global, regional, and national prevalence of overweight and obesity in children and adults during 1980-2013: a systematic analysis for the Global Burden of Disease Study 2013. Lancet 2014; 384: 766-81. doi.org/10.1016/ S0140-6736(14)60460-8

18. Timmis A, Townsend N, Gale C, et al. ESC Cardiovascular Disease Statistics 2017. Eur Heart J 2018; 39: 508-79. doi: 10.1093/ eurheartj/ehx628.

19. Kékes E, Barna I, Daiki T, et al. Magyarország antropometriai helyzete az országos népegészségügyi szûrés alapján (20102017). Adatelemzés, összefüggés-vizsgálat - I. rész. Hypertonia és Nephrologia 2018; 22(4): 155-63.

20. Kékes E. Cardiovascularis kockázati tényezők és kockázatbecslés. LAM 2013; 23(10-11): 489-501.

21. World Bank. World Development Indicators, 2013. Washington, DC: World Bank, 2013.http://www.worldbank.org/en/news/press-release/2013/04/18/world-development-indicators-2013-released

22. Kardiovaszkuláris prevenció a klinikai gyakorlatban (szerk Tóth K, Vértes A, Szabados E, Tonelli M, Vályi P.) Viviankom-2002 Kft. Budapest 2017

23. Vályi $P$. Betegségügy, egészségügy vagy egész-ség-ügy a mindennapi orvosi gyakorlatban. LAM 2015; 25: 537-42.

24. World Diabetes Day https://www.worlddiabetesday.org

25. Beaney $T$, Schutte AE, Tomaszewski M, et al. on behalf of the MMM Investigators. May Measurement Month 2017: An analysisof blood pressure screening results worldwide. The Lancet Global Health. May 2018. doi:.org/10.1016/S2214-109X (18)30259-6

26. Witter S, Fretheim A, Kessy FL, Lindahl AK. Paying for performance to improve the delivery of health interventions in low- and middle-income countries. Cochrane Database Syst Rev 2012; 2:
CD007899. doi.org/10.1002/14651858.CD007899.pub2

27. Mahbubani K. The great convergence. Asia, the West, and the logic of one world. New York: Public Affairs, 2013.

28. Bibbins-Domingo K, Chertow GM, Coxson PG, et al. Projected Effect of Dietary Salt Reductions on Future. Cardiovascular Disease. N Engl J Med 2010; 362: 590-9. doi.org/10.1056/NEJMoa0907355 29. Kiss I, Barna I, Daiki T, Dankovics G, Kékes E. A népegészségügyi stratégiák és szürővizsgálatok megvalósulása Magyarország Átfogó Egészségvédelmi Szűrőprogramja (MÁESZ) eredményeinek tükrében (2010-2017). LAM 2018; 28: 99-105.

30. Éljen $140 / 90$ alatt. Hatékony vérnyomáscsökkentés a betegegyüttmüködés segítségével. (szerk Kiss I. és Kékes E.) Budapest: Literatura Medica Kft.; 2015.

31. Tóth $\mathrm{K}$, Sándor B. Kardiológia Népegészségügyi szemmel. IME 2018; 18: 26-9.

32. Clark RA, Conway A, Poulsen V, Keech W, Tirimacco R, Tideman P. Alternative models of cardiac rehabilitation: a systematic review. Eur J Prev Cardiol 2015; 22: 35-74. doi.org/10.1177/2047487313501093 33. Hamilton SJ, Mills B, Birch EM, Thompson SC. Smartphones in the secondary prevention of cardiovascular disease: a systematic review. BMC Cardiovasc Disord 2018 Feb 7;18(1): 25. doi: 10.1186/ s12872-018-0764-x.

34. Kékes E, Szegedi J, Kiss I. A telemedicina szerepe az orvos-beteg együttműködés optimális megoldása érdekében hypertonia betegségben. Hypertonia\&Nephrologia 2018; 22: (Suppl 2): 4-6.

35. Morel CM, Acharya T, Broun D, et al. Health innovation networks to help developing countries address neglected diseases. Science 2005; 309: 401-4. doi.org/10.1126/science.1115538

36. Clift C. Identifying sustainable methods for improving global health security and access to health care. Chatham House Working Paper, April 2013. http://www.chathamhouse.org/publications/ papers/view/192809

37. Elovainio R, Evans DB. Raising and spending domestic money for health. Chatham House Working Paper, May 2013. http://www. chathamhouse.org/publications/papers/view/191335

38. World Health Organization. Draft comprehensive global monitoring framework and targets for the prevention and control of noncommunicable diseases.2015. Genf. http://apps. who.int/gb/ebwha/ pdf_files/WHA66/A66_8-en

39. Smith SC Jr, Chen D, Collins A, et al. Moving from political declaration to action on reducing the global burden of cardiovascular diseases: a statement from the Global Cardiovascular Disease Taskforce, Circulation 2013; 128: 2546-8. doi.org/10.1161/CIR. 0b013e3182a93504

40. Andréka P, Ablonczy L, Csató G, ET AL. Nemzeti Népegészségügyi Stratégia, Keringési Betegségek Budapest: P. 20181-193.

41. WHO. Prevention and control of NCDs: priorities for investment. Discussion paper for the First Global Ministerial Conference on Healthy Lifestyles and Noncommunicable Disease Control. Geneva: World Health Organization, 2011. www.who.int/nmh/events/ moscow_ncds_2011/conference_documents/moscow_declaration_en.pdf?ua $=1$

42. Eurostat 2016. Mortality and life expectancy. https:// hec.europa. eu/eurostat /statistics-explained/index.php/Mortality_and_life_expectancy_statistics. 